\title{
Some Observations on the Nitrogen Metabolism of Rumen Proteolytic Bacteria
}

\author{
By A. R. ABOU AKKADA* AND T. H. BLACKBURN \\ The Rowett Research Institute, Bucksburn, Aberdeen
}

(Received 1 November 1962)

\begin{abstract}
SUMMARY
Isolates from the rumens of sheep of presumptively identified Bacteroides amylophilus, B. ruminicola, species of Bacteroides, Selenomonas, Butyrivibrio, Bacillus, Eubacterium, Clostridium and Gram-positive cocci were found to be proteolytic. Some of these strains also had exopeptidase and amidase activity, but significant deaminase activity was rare. Most of the strains preferentially utilized ammonia in synthesizing cellular constituents in media containing preformed amino acids. Few of the strains had urease activity.
\end{abstract}

\section{INTRODUCTION}

In a survey of the proteolytic bacteria from the sheep rumen (Blackburn \& Hobson, 1962) it was found that proteolytic activity was possessed by strains of many kinds of bacteria. Proteolytic bacteria were selected on the basis of their capacity to produce some visible change in casein agar roll tubes, and overall proteolytic activity in liquid cultures was measured by determining the decrease in trichloroacetic acid-precipitated protein. The cultures isolated were not stored for more detailed investigation partly because of the difficulty of keeping many of the bacteria viable over prolonged periods. For the present work proteolytic strains of bacteria were re-isolated to provide further confirmation that the previously described bacteria are found in the rumen at all times, and the nitrogen metabolism was investigated in more detail. Previously it was found that a well-reduced medium was needed for good growth of proteolytic bacteria, and for most isolations media containing cysteine + dithionite were used, although media with cysteine alone were used initially. In the present work both types of media were used. As before, media containing a number of carbohydrates were used, to ensure that as large a number as possible of bacterial types grew. Since, as previously noted, proteolytic activity in liquid medium did not always coincide with a visible change in a solid casein medium, representatives of all colonial types which grew in the primary media were tested for proteolysis in liquid media.

\section{METHODS}

Sheep. Isolations were made from five sheep; sheep 6 was fed on a partiallydefined casein diet, sheep 190, 74, 93 and 95 on hay-concentrate diets (Blackburn \& Hobson, 1962). Sheep 95 by special experimental procedure contained no protozoa (Eadie \& Hobson, 1962).

* Present address: Faculty of Agriculture, University of Alexandria, Alexandria, Egypt. 
Isolation and identification. The methods used were as previously described (Blackburn \& Hobson, 1962), with the following modifications. Carbohydrates were added at $0.1 \%$ concentration to discourage colonies from spreading. Isolation media $1 \mathrm{D}$ and $1 \mathrm{C}, 2 \mathrm{D}$ and $2 \mathrm{C}, 3 \mathrm{D}$ and $3 \mathrm{C}, 4 \mathrm{D}$ and $4 \mathrm{C}$ contained, respectively, no carbohydrate, carboxymethyl cellulose, glucose, and a mixture of xylose, maltose and cellobiose. Media designated $\mathbf{D}$ were reduced by cysteine + dithionite, media designated $\mathrm{c}$ were reduced by cysteine alone. Colony development was followed, any changes produced in the casein noted, and finally representatives of all colony types subcultured on agar slopes, a count being made of all similar colony types. The morphology of the organisms growing on the slopes was examined and the strains were inoculated into casein liquid medium to determine their proteolytic activity (Blackburn \& Hobson, 1960b). Only proteolytic strains were examined further.

Nitrogen metabolism. This was studied in a basal medium to which various additions were made as indicated in Table 1 . The media were incubated for 4 days before analysis.

Table 1. Additions to the basal medium used in studying the nitrogen metabolism of proteolytic bacteria

\begin{tabular}{|c|c|c|c|c|c|c|}
\hline \multirow{2}{*}{$\begin{array}{l}\text { Additions and } \\
\text { concentration }\end{array}$} & \multicolumn{6}{|c|}{ Media } \\
\hline & C.Y. $\mathrm{NH}_{3}$ & T.Y. $\mathrm{NH}_{3}$ & $\mathbf{T}$ & T. $\mathbf{N H}_{3}$ & T.A. $\mathbf{N H}_{3}$ & T.Y.U. \\
\hline Casein 0.5\% & + & - & - & - & - & - \\
\hline Tryptose $\mathbf{0 . 5} \%$ & - & + & + & + & + & + \\
\hline Yeast extract $0.1 \%$ & + & + & - & - & - & + \\
\hline Urea $0.3 \%$ & - & - & - & - & - & + \\
\hline Asparagine 0.132\% & - & - & - & - & + & - \\
\hline$\left(\mathrm{NH}_{4}\right)_{2} \mathrm{SO}_{4} 0.3 \%$ & + & + & - & + & + & - \\
\hline
\end{tabular}

$+=$ The addition is present in the medium.

- = The addition is not present in the medium. Additions were at final concentrations as described above.

The basal medium contained per $100 \mathrm{ml}$. : salt solutions $a$ and $b$ (Blackburn \& Hobson, 1962) minus ammonium sulphate, $15 \mathrm{ml}$. of each; centrifuged rumen fluid, $10 \mathrm{ml}$; sodium bicarbonate 0.5 g.; L-cysteine-HCl, 0.05 g.; dithionite, 0.003 g.; pheno-safranine, 0.0001 g.; xylose, maltose and cellobiose, $0 \cdot 1 \mathrm{~g}$. of each.

Analytical methods. Uninoculated media were used as controls. A micro-Kjeldahl method (McKenzie \& Wallace, 1954) was used to determine nitrogen in centrifuged bacterial deposits, and for trichloroacetic acid (TCA) soluble- and insoluble-nitrogen (Blackburn \& Hobson, 1960a). Proteolytic activity was measured by decrease in TCA-insoluble nitrogen. Urease activity was measured by the production of ammonia from urea, amidase activity was measured by the production of ammonia from asparagine (Conway, 1957). Deaminative activity was measured by the production of ammonia in C.Y. $\mathrm{NH}_{3}$, T.Y. $\mathrm{NH}_{3}$ and T media (Table 1). A measure of the amino acid and peptide-nitrogen production in C.Y. $\mathrm{NH}_{3}$ medium was obtained as follows. Samples $(1.0 \mathrm{ml}$.) of the culture media were adjusted to $\mathrm{pH} 4.0$ by adding citric acid $(0 \cdot 1 \mathrm{M})$ and diluted to $10 \mathrm{ml}$. by adding phosphate-citrate buffer (pH 4.0). After filtration through Whatman No. 42 paper, samples $(0.1 \mathrm{ml}$.) of the filtrate were used for determining amino acid-nitrogen by the method of Lampson \& Singher (1960) as modified by Abou Akkada \& Howard (1962). Dipeptide nitrogen 
was similarly determined on another sample of the culture adjusted to $\mathrm{pH} \mathrm{5.5}$. Polypeptide-nitrogen was determined by mixing $1 \mathrm{ml}$. of the cell-free supernatant fluid of a centrifuged culture with $2 \mathrm{ml} .10 \%(\mathrm{w} / \mathrm{v})$ trichloroacetic acid, standing for $1 \mathrm{hr}$. and filtering through Whatman No. 42 paper. Samples $(1.0 \mathrm{ml}$.) of the filtrate were mixed with $2 \mathrm{~N}-\mathrm{NaOH}, 1 \mathrm{ml}$, and biuret reagent, $8 \mathrm{ml}$., and the procedure of Layne (1957) followed. The qualitative and quantitative determinations of volatile fatty acids, except formic acid, were as previously described (Abou Akkada \& Howard, 1960). Formic acid was detected by the ninhydrin method of Burness \& King (1958). Quantitative determination of formic acid was carried out on a distillate of the culture medium by the colorimetric micro-method of Grant (1947). Succinic and lactic acids were identified by paper chromatography of the culture medium by a method similar to that of Stark, Goodban \& Owens (1951).

\section{RESULTS}

One series of isolations was made from each sheep, 6, 190, 74, 93 and 95 and the runs were named $B, C, D, E$ and $F$, respectively. The eight isolation media have been described (see page 462). The isolated bacteria were named according to the particular run, the medium and the dilution in which they appeared. Thus $D 1 \mathrm{D} 6$ would be a strain isolated in run $\mathrm{D}$ (sheep 74) from a medium containing no carbohydrate, reduced by cysteine + dithionite and occurring at $10^{6}$ organisms $/ \mathrm{ml}$. rumen fluid. A further number, e.g. D1 D63, would differentiate that strain from others isolated from the same dilution roll tube.

Media reduced by cysteine + dithionite were no more effective than those reduced by cysteine alone in producing a proteolytic flora. No particular carbohydrate source stimulated the growth of proteolytic bacteria but glucose appeared to have an inhibitory effect. Proteolytic colonies could easily be seen in the media containing no carbohydrate or carboxymethyl cellulose after incubation for 4 days. Probably no particular bacterial proteolytic type was associated exclusively with any sheep. Some colonies which produced no definite change or zone in the agar roll tubes produced marked hydrolysis of casein in liquid culture and vice versa. Proteolytic bacteria did not contribute to more than $10 \%$ of the viable population on these media.

Representative proteolytic bacterial strains from each run were selected and these strains (32) were identified and their nitrogen nutrition examined. The properties of the bacteria were determined by using the same range of tests as did Blackburn \& Hobson (1962) and they were classified in a similar manner. The products of fermentation which are helpful in classifying the bacteria are listed in Table 2.

\section{Group 1. Bacteroides}

(a) Bacteroides amylophilus. These seven strains (в3 D71, в3 D75, Е4с66, Е1 D6, c1 c6, c2 c62, D1 D61) were pleomorphic Gram-negative $1 \mu$ coccoids, non-motile, and fermented dextrin, glycogen, starch and maltose.

(b) Bacteroides ruminicola. These three isolates (E2c7, E4D8, F2D7) were pleomorphic Gram-negative, non-motile rods 0.3 to $0.5 \times 1.0 \mu$, and fermented a wide range of carbohydrates. 
(c) Bacteroides sp. This strain ( $\mathrm{4} 4 \mathrm{c6}$ ) was a Gram-negative small curved $0.4 \times 1.4 \mu$ pointed-end rod; it produced butyric acid from glucose.

Group 2. Lachnospira. This single isolate, B2D8, was a Gram-negative, long $(0.4 \times 2.5 \mu)$, slightly curved, rod occurring in chains. It fermented only glycerol, glucose, mannose, maltose, sucrose, trehalose, carboxymethyl cellulose and cellobiose. The original colony produced no visible change in the casein of the roll tube.

Table 2. Fermentation products in fluid medium after 4 days incubation at $38^{\circ} \mathrm{C}$

\begin{tabular}{|c|c|c|c|c|c|c|c|c|c|c|}
\hline \multirow[b]{2}{*}{ Isolate } & \multirow[b]{2}{*}{$\begin{array}{c}\text { Sugar } \\
\text { fer- } \\
\text { mented }\end{array}$} & \multirow{2}{*}{$\begin{array}{l}\text { Total } \uparrow \\
\text { VFA } \\
\text { m-equi- } \\
\text { valents/ } \\
100 \text { ml. }\end{array}$} & \multirow[b]{2}{*}{$\begin{array}{l}\text { Succinic } \\
\text { acid }\end{array}$} & \multirow[b]{2}{*}{$\begin{array}{c}\text { Lactic } \\
\text { acid }\end{array}$} & \multicolumn{4}{|c|}{$\%$ of total VFA } & \multirow[b]{2}{*}{$\begin{array}{c}\text { Final } \\
\text { pH }\end{array}$} & \multirow[b]{2}{*}{ Group } \\
\hline & & & & & Formic & Acetic & $\begin{array}{c}\text { Pro- } \\
\text { pionic }\end{array}$ & Butyric & & \\
\hline B8D71 & Maltose & $6 \cdot 5$ & + & - & 25 & 69 & 7 & 4 & $6 \cdot 3$ & \\
\hline B3 D75 & Maltose & 6.9 & + & - & 25 & 58 & 7 & 5 & $6 \cdot 4$ & \\
\hline E4, 6 & Maltose & $\mathbf{3 \cdot 2}$ & + & - & 22 & 69 & 8 & 4 & $5 \cdot 1$ & \\
\hline El D6 & Maltose & $*$ & + & - & $\mathbf{3 0}$ & 60 & 7 & 4 & $*$ & \\
\hline clc6 & Maltose & $2 \cdot 9$ & + & - & 43 & 44 & 9 & 4 & $7 \cdot 1$ & \\
\hline c2 c62 & Maltose & $*$ & $*$ & $\star$ & $*$ & $*$ & $*$ & $*$ & $*$ & 1 \\
\hline Dl D61 & Maltose & $\mathbf{3 \cdot 7}$ & + & - & 30 & 60 & 7 & 4 & $5 \cdot 3$ & \\
\hline $\mathrm{E} 2 \mathrm{C7}$ & Glucose & $1 \cdot 3$ & + & + & 80 & 50 & 17 & 2 & $5 \cdot 2$ & \\
\hline E4 D8 & Glucose & $1 \cdot 8$ & + & + & 0 & 84 & 11 & 2 & $5 \cdot 8$ & \\
\hline F2D & Glucose & $1 \cdot 2$ & + & + & 30 & 52 & 14 & 4 & $5 \cdot 6$ & \\
\hline $\mathrm{E} 4 \mathrm{C} 6$ & Glucose & $5 \cdot 3$ & + & - & 30 & 21 & 4 & 49 & $5 \cdot 4$ & \\
\hline B2 D8 & Maltose & $7 \cdot 3$ & + & - & 30 & 58 & 7 & $\mathbf{5}$ & $6 \cdot 3$ & 2 \\
\hline D1 D4 & Glucose & $2 \cdot 0$ & + & - & 22 & 16 & 8 & 47 & * & \\
\hline D4 06 & Glucose & $4 \cdot 3$ & + & + & 27 & 27 & 4 & 28 & $*$ & \\
\hline F1 D6 & Glucose & $2 \cdot 5$ & + & + & 32 & 28 & 6 & 46 & $5 \cdot 6$ & \\
\hline F2D6 & Glucose & $3 \cdot 4$ & + & + & $\mathbf{0}$ & $\mathbf{3 0}$ & 4 & 65 & $5 \cdot 5$ & 8 \\
\hline F3 D61 & Glucose & $3 \cdot 1$ & + & + & 20 & 18 & 6 & 52 & $5 \cdot 3$ & \\
\hline F4c6 & Glucose & $2 \cdot 1$ & + & + & o & 6 & 48 & 42 & 4.5 & \\
\hline E2c63 & Glucose & 1.8 & - & + & 10 & 57 & 9 & 25 & $4 \cdot 6$ & \\
\hline E2 C65 & Glucose & 1.6 & - & + & 8 & 53 & 10 & 28 & $4 \cdot 4$ & \\
\hline E2 c62 & Glucose & $1 \cdot 7$ & - & + & 24 & $\mathbf{B 5}$ & 6 & 24 & $4 \cdot 4$ & \\
\hline F2C61 & Glucose & $1 \cdot 4$ & - & + & $\mathbf{0}$ & 78 & 20 & 5 & $5 \cdot 0$ & 4 \\
\hline F4c6 & Glucose & $1 \cdot 9$ & + & + & 12 & 51 & $\mathbf{3 4}$ & 3 & 4.5 & \\
\hline F4D71 & Glucose & $2 \cdot 1$ & - & + & $*$ & 46 & 27 & 9 & $4 \cdot 2$ & \\
\hline F3 D6 & Glucose & $1 \cdot 8$ & - & + & 27 & 50 & 18 & $\mathbf{5}$ & $5 \cdot 0$ & \\
\hline c2 c 6 & Maltose & $6 \cdot 3$ & - & - & 20 & 57 & 8 & 22 & $6 \cdot 1$ & \\
\hline E2c64 & Glucose & 1.9 & - & + & 24 & 19 & 7 & 50 & $4 \cdot 4$ & \\
\hline D2D6 & Glucose & 1.0 & + & + & 51 & 38 & 7 & 4 & $*$ & 5 \\
\hline El C7 & Glucose & 1.5 & - & + & 8 & 53 & 20 & 3 & $5 \cdot 8$ & \\
\hline F4 17 & Glucose & $1 \cdot 2$ & - & + & $\mathbf{0}$ & 58 & 13 & 19 & $4 \cdot 2$ & \\
\hline F3 c6 & Glucose & $4 \cdot 3$ & - & + & 22 & 25 & 6 & 28 & $4 \cdot 8$ & 6 \\
\hline F1 D8 & Glucose & $1 \cdot 3$ & - & + & 30 & 49 & 13 & $\mathbf{9}$ & 4.7 & \\
\hline
\end{tabular}

Group 3. Butyrivibrio. These six isolates (D1D4, D4D6, F1D6, F2D6, F3D61, F4.6) were Gram-negative curved rods 0.3 to $0.5 \times 1$ to $2.5 \mu$, motile (except D1 D4) by a single polar flagellum, and fermented a wide variety of carbohydrates.

Group 4. Selenomonas ruminantium. These eight isolates (E2 c63, E2 c65, E2 c62, F2c61, F4C6, F4D71, F3D6, C2c6) were large Gram-negative crescents 0.4 to 
$1.2 \times 2.0$ to $4.0 \mu$, motile with flagellation similar to that described by Hobson \& Mann (1961). Isolate F2 c61 could be classified as Selenomonas ruminantium var. lactyliticus.

Group 5. Gram-positive or Gram-variable long rods

(a) Eubacterium. Isolate E2 C64 was a non-motile, non-sporing, $\mathbf{0 . 6} \times \mathbf{2 \cdot 3} \mu \mathrm{rod}$ in fairly long chains, and fermented arabinose, dextrin, fructose, glucose, galactose, glycogen, inulin, lactose, mannitol, mannose, maltose, sucrose and starch.

(b) Bacillus. Organism D2D6 was a Gram-positive, non-sporing $0.9 \times 2 \mu$ facultative anaerobic rod; it fermented a moderate range of carbohydrates.

(c) Clostridium. The isolate $\mathrm{E1}$ c7 was a Gram-variable non-motile rod $0 \cdot 4 \times 2 \cdot 4 \mu$ with a swollen medial spore, and fermented a moderate range of carbohydrates.

Group 6. Gram-positive cocci

The isolates F4D7, F3C6, F1D8, all 1.0 $\mu$ diameter cocci, were included in this group; Fl $\mathbf{D 8}$ was facultatively anaerobic.

\section{Peptidase activity}

The end products of casein degradation by proteolytic bacteria were mainly amino acids and polypeptides (Table 3). No dipeptides were ever observed. Endopeptidase or proteinase activity was indicated by the percentage breakdown in casein after growth in casein liquid medium, exopeptidase activity by the ratio of amino acid-nitrogen to total amino acid + polypeptide-nitrogen (Table 3). Proteolytic activity varied within the presumptively identified groups as did exopeptidase activity and there was no correlation between the two except that the Bacteroides amylophilus strains had mostly high proteolytic activity and low exopeptidase activity while the $B$. ruminicola group had consistently high exopeptidase activity. No generalizations could be made regarding the Butyrivibrio and Selenomonas groups.

\section{Ammonia production}

The results of experiments to test ammonia production or utilization are tabulated (Table 4) in the form of increase or decrease in ammonia concentration over the control after incubation. The amount of bacterial growth was estimated only for the C.Y. $\mathbf{N H}_{3}$ medium. In some cases this gave a very low value because of autolysis of the organisms, and sometimes the value was too high because denatured casein was sedimented with the centrifuge-deposit of organisms, this often being associated with amidase activity (Table 4). Probably the average bacterial nitrogen content should have been 1.0 to $2 \cdot 0 \mu$ equivalents nitrogen $/ \mathrm{ml}$. culture fluid. There was very little evidence of ammonia production from casein in the medium C.Y. $\mathrm{NH}_{3}$; in general there was an uptake of ammonia corresponding roughly with the bacterial nitrogen. Deamination could result in an increase in ammonia in all the media. Media C.Y. $\mathrm{NH}_{3}$, T.Y. $\mathrm{NH}_{3}$ and T.A. $\mathrm{NH}_{3}$ contained 5.0, 0.5 and $10.0 \mu$ equivalents amide-nitrogen/ml., respectively, and thus amidase activity could also release ammonia in these media. Urease activity would be detected in T.Y.U. medium. The T.Y. $\mathbf{N H}_{3}$ medium differed from the C.Y. $\mathbf{N H}_{3}$ in containing a trypsin-hydrolysed casein, tryptose. In T.Y. $\mathbf{N H}_{3}$ medium as in C.Y. $\mathbf{N H}_{3}$ medium there was generally a net uptake of ammonia and there was no evidence that tryptose was a better 
substrate for deaminases than was casein. A comparison between media $\mathbf{T}$ and $\mathbf{T} \cdot \mathbf{N H}_{\mathbf{3}}$ showed that in many cases the higher initial ammonia level resulted in decreased net production of ammonia. This was not true of the Butyrivibrio group 3. A comparison between T. $\mathbf{N H}_{3}$ and T.A. $\mathbf{N H}_{3}$ showed the amount of amidase activity. This property was found in all three strains of Bacteroides ruminicola group 1, and occurred

Table 3. The products of casein hydrolysis after 4 days of incubation at $39^{\circ} \mathrm{C}$

\begin{tabular}{|c|c|c|c|c|c|}
\hline Isolate & $\begin{array}{c}\text { Casein } \\
\text { hydrolysed } \\
(\%)\end{array}$ & $\begin{array}{l}\text { Amino } \\
\text { acid-nitrogen } \\
\% \text { total } \\
\text { casein- } \\
\text { nitrogen }\end{array}$ & $\begin{array}{c}\text { Polypeptide- } \\
\text { nitrogen as } \\
\% \text { total } \\
\text { casein- } \\
\text { nitrogen }\end{array}$ & $\begin{array}{c}\text { Amino } \\
\text { acid-nitrogen } \\
\text { as } \% \text { non- } \\
\text { protein- } \\
\text { nitrogen }\end{array}$ & Group \\
\hline B3D71 & 86 & 15 & 61 & 20 & \\
\hline B3 D75 & 86 & 14 & 65 & 18 & \\
\hline E4c6 & 30 & 5 & 26 & 15 & \\
\hline E1 D6 & 35 & 11 & 26 & 34 & \\
\hline c1 c6 & 90 & 16 & 68 & 20 & \\
\hline c2 c62 & 94 & 31 & 54 & $\mathbf{3 7}$ & 1 \\
\hline D1 D61 & 87 & 19 & $\mathbf{5 9}$ & 24 & \\
\hline E2 c7 & 28 & 8 & 10 & 44 & \\
\hline E4D8 & 97 & 64 & 17 & 79 & \\
\hline F2 D7 & 46 & 23 & 26 & 45 & \\
\hline E4 c6 & 28 & $\mathbf{9}$ & 18 & 35 & \\
\hline B2 D8 & $\mathbf{3 3}$ & 5 & 29 & 14 & 2 \\
\hline D1 D4 & 55 & 23 & 29 & 44 & \\
\hline D4 D6 & 16 & 5 & 13 & 28 & \\
\hline F1 D6 & 81 & 19 & 58 & 25 & 8 \\
\hline F2D6 & 66 & 7 & 29 & 18 & 8 \\
\hline F3D61 & 43 & 18 & 26 & 42 & \\
\hline F4, 6 & 87 & 23 & 66 & 26 & \\
\hline E2 c63 & 93 & 36 & 57 & 38 & \\
\hline E2c65 & 49 & 7 & 39 & 16 & \\
\hline E2c62 & 40 & 6 & 35 & 15 & \\
\hline F2c61 & 55 & 15 & 33 & 31 & 4 \\
\hline F4c6 & 12 & $\mathbf{2}$ & 8 & 16 & \\
\hline F4 $D 71$ & 96 & 17 & 71 & 20 & \\
\hline F3D6 & 21 & 4 & 14 & 20 & \\
\hline c2 c6 & 34 & 8 & 27 & $\mathbf{2 3}^{\prime}$ & \\
\hline E2c64 & 47 & 6 & 42 & 13) & \\
\hline D2 D6 & 26 & 6 & 17 & $26\}$ & 5 \\
\hline E1 C7 & 90 & 61 & 27 & 69J & \\
\hline F4 D7 & 93 & 15 & 71 & 18) & \\
\hline F3 c6 & 12 & $\mathbf{2}$ & 14 & $11\}$ & 6 \\
\hline F1 D8 & 79 & 10 & 64 & 14 J & \\
\hline
\end{tabular}

The initial casein concentration was $50 \mu$-equivalents nitrogen/ml. of medium C.Y. $\mathrm{NH}_{3}$, the composition of which is in Table 1.

in Butyrivibrio group 3 (strains F2D6, F3D61, F4C6); in Selenomonas group 4 (strains E2 c63, E2c65, F4 C6, F4D71, F3 D6) and in all strains in groups 5 and 6. The strains E4 D8, F2D7 of $B$. ruminicola, Butyrivibrio F3D61, Selenomonas strains F3 D6 and possibly F2 C61, F4, 66, F4D71, all strains in group 5, strain F4D7 in group 6 were considered to show some degree of deaminative activity. No significant urease activity was shown by any of these bacteria except possibly F4D7 and F2 D6, and even there only a small amount of the substrate was attacked. 


\section{Table 4. Production of ammonia from various substrates after 4 days of incubation at $39^{\circ}$}

The results are expressed in $\mu$-equivalents of nitrogen per ml. of culture fluid. The initial concentrations of ammonia-nitrogen in $\mu$-equivalents per ml. of uninoculated C.Y. $\mathrm{NH}_{3}, \mathrm{~T} . \mathrm{Y} . \mathrm{NH}_{3}, \mathrm{~T}$, T.A. $\mathrm{NH}_{3}$, T. $\mathrm{NH}_{3}$ and T.Y.U. were $15 \cdot 0,17 \cdot 0,1 \cdot 5,15 \cdot 3,15 \cdot 3$ and 4.9 approximately, depending on the batch of medium. Media composition in Table 1.

\begin{tabular}{|c|c|c|c|c|c|c|c|c|}
\hline \multirow[b]{2}{*}{ Isolate } & \multirow{2}{*}{$\begin{array}{c}\text { Bacterial } \\
\text { nitrogen } \\
\text { C.Y. } \text { NH }_{3}\end{array}$} & \multicolumn{6}{|c|}{ Increase in ammonia nitrogen } & \multirow[b]{2}{*}{ Group } \\
\hline & & C.Y. $\mathbf{N H}_{3}$ & T.Y. $\mathbf{N H}_{3}$ & $\mathbf{T}$ & T. $\mathbf{N H}_{\mathbf{3}}$ & T.A. $\mathbf{N H}_{3}$ & T.Y.U. & \\
\hline B3D71 & 0.00 & $-3 \cdot 72$ & $0 \cdot 48$ & -0.54 & * & * & $*$ & \\
\hline B3 D75 & 0.00 & -0.48 & -0.46 & -0.07 & $*$ & $*$ & $*$ & \\
\hline $\mathrm{E4c6}$ & 0.60 & * & $-2 \cdot 86$ & -0.86 & $-1 \cdot 64$ & 0.71 & $1 \cdot 21$ & \\
\hline E1 D6 & 0.90 & $*$ & $-0 \cdot 11$ & 0.35 & $-1 \cdot 19$ & 0.71 & $-1 \cdot 07$ & \\
\hline c1 c6 & 0.71 & $-1 \cdot 18$ & $-0 \cdot 34$ & -0.15 & $*$ & $*$ & $*$ & \\
\hline c2 c62 & $*$ & -0.34 & $-1 \cdot 43$ & $\mathbf{0 . 3 3}$ & $-0 \cdot 14$ & * & 0.49 & 1 \\
\hline D1 D61 & 0.00 & $-1 \cdot 64$ & $-2 \cdot 86$ & -0.50 & $-2 \cdot 00$ & $-1 \cdot 64$ & $-\mathbf{3} \cdot 00$ & \\
\hline E2 C7 & $0 \cdot 63$ & $-1 \cdot 07$ & $-1 \cdot 43$ & $0 \cdot 63$ & -0.93 & $3 \cdot 14$ & 0.50 & \\
\hline$E 4 D 8$ & $6 \cdot 45$ & $13 \cdot 32$ & 3.57 & 6.78 & $-\mathbf{3} \cdot 00$ & $15 \cdot 71$ & $\mathbf{3} \cdot 58$ & \\
\hline F2 D7 & $7 \cdot 85$ & $4 \cdot 28$ & -0.71 & 1.47 & -0.71 & $3 \cdot 57$ & $4 \cdot 64$ & \\
\hline E4, c6 & 4.67 & $*$ & -1.46 & $-0 \cdot 64$ & -0.53 & $*$ & $-1 \cdot 26$ & \\
\hline B2 D8 & 1.93 & $-2 \cdot 00$ & $0 \cdot 19$ & -0.59 & $*$ & * & $*$ & 2 \\
\hline D1 D4 & $1 \cdot 60$ & $-6 \cdot 72$ & $-1 \cdot 00$ & $-1 \cdot 36$ & -1.93 & -0.87 & -0.60 & \\
\hline D4D6 & $1 \cdot 30$ & $-0 \cdot 38$ & $-0 \cdot 27$ & -0.28 & $0 \cdot 43$ & $-0 \cdot 67$ & -0.20 & \\
\hline F1 D6 & $2 \cdot 00$ & $-1 \cdot 64$ & $-3 \cdot 66$ & -0.07 & 0.00 & 0.56 & $0 \cdot 18$ & \\
\hline F2D6 & 4.07 & -1.93 & $-0 \cdot 27$ & 0.09 & $0 \cdot 86$ & $16 \cdot 16$ & $6 \cdot 56$ & $\mathbf{3}$ \\
\hline F3 D61 & $2 \cdot 71$ & $\mathbf{2 \cdot 8 6}$ & $\mathbf{3} \cdot \mathbf{3 6}$ & 0.09 & 0.93 & $15 \cdot 85$ & $2 \cdot 71$ & \\
\hline F4c6 & 5.00 & 0.24 & -0.48 & 1.07 & $2 \cdot 50$ & $16 \cdot 43$ & $1 \cdot 79$ & \\
\hline E2 c63 & 10.91 & $*$ & 0.91 & $\mathbf{0 . 3 6}$ & -1.53 & 8.71 & 0.50 & \\
\hline E2 c65 & $\mathbf{9} \cdot 14$ & * & $-0 \cdot 34$ & 1.00 & -1.33 & $9 \cdot 30$ & $0 \cdot 15$ & \\
\hline E2 c62 & $7 \cdot 14$ & $*$ & 0.48 & 0.50 & -0.86 & 0.71 & $1 \cdot 09$ & \\
\hline F2c61 & 1.93 & -1.93 & $-3 \cdot 21$ & $1 \cdot 50$ & $\mathbf{1} \cdot \mathbf{3 2}$ & $1 \cdot 19$ & 0.46 & 4 \\
\hline F4c6 & $2 \cdot 50$ & $-2 \cdot 64$ & $-3 \cdot 24$ & $1 \cdot 14$ & $\mathbf{3 \cdot 3 1}$ & $15 \cdot 30$ & 0.51 & 4 \\
\hline F4D71 & 1.93 & $-2 \cdot 00$ & $-4 \cdot 96$ & $1 \cdot 29$ & 1.50 & $13 \cdot 83$ & 1.79 & \\
\hline F3 D6 & 0.23 & $1 \cdot 14$ & 0.00 & $5 \cdot 07$ & 0.71 & $5 \cdot 79$ & 1.50 & \\
\hline C2 c6 & 3.07 & $-0 \cdot 13$ & -1.00 & -0.93 & $-0 \cdot 26$ & $0 \cdot 81$ & $-0 \cdot 11$ & \\
\hline E2 c64 & $7 \cdot 85$ & * & $-0 \cdot 26$ & $4 \cdot 14$ & $-1 \cdot 00$ & $5 \cdot 71$ & $-2 \cdot 43$ & \\
\hline D2D6 & $8 \cdot 14$ & 1.50 & $2 \cdot 07$ & 0.90 & $0 \cdot 19$ & $3 \cdot 36$ & -0.02 & 5 \\
\hline E1 C7 & 4.72 & $13 \cdot 36$ & $4 \cdot 36$ & $13 \cdot 14$ & $2 \cdot 71$ & $19 \cdot 57$ & $\mathbf{3 \cdot 1 4}$ & \\
\hline F4. 77 & $2 \cdot 50$ & 0.00 & $-3 \cdot 86$ & 1.72 & 3.78 & $17 \cdot 14$ & $8 \cdot 72$ & \\
\hline F3c6 & 0.71 & $-1 \cdot 29$ & -0.71 & $1 \cdot 00$ & -2.00 & 4.50 & $2 \cdot 07$ & 6 \\
\hline F1 D8 & $1 \cdot 20$ & -0.68 & $\mathbf{0} \cdot \mathbf{3 3}$ & $1 \cdot 14$ & $-2 \cdot 00$ & 1.79 & $*$ & \\
\hline
\end{tabular}

\section{DISCUSSION}

Species of Bacteroides, Selenomonas and Butyrivibrio have again been found associated with protein hydrolysis in the sheep rumen. This is in keeping with the observations of Blackburn \& Hobson (1962), but none of the large Gram-negative butyric acid-forming rods (group 5, Blackburn \& Hobson, 1962) was isolated. Proteolytic bacteria did not constitute a major portion of the strains which appeared on the isolation media, thus differing from the observations of Fulghum, King \& Moore (1958) with cattle who found $30 \%$ of their total count to be proteolytic. As reported previously (Blackburn \& Hobson, 1962) no particular carbohydrate encouraged the 
growth of all proteolytic bacteria but maltose was effective in culturing Bacteroides amylophilus, a particularly active protease producer. The total absence of carbohydrate or the presence of a less readily attacked carbohydrate such as carboxymethyl cellulose, resulted in the isolation of strains that might otherwise have been overgrown. Occasionally strains (e.g. c1 c6, c2 c62, F2 c61) which had produced no change in the casein of the isolation medium, were found to be actively proteolytic in liquid culture. Generally, strains which produced a clear zone in the casein of the isolation medium subsequently produced hydrolysis of casein in liquid culture, but exceptions to this were noted, especially where the zone was not well defined.

A pure proteolytic enzyme such as crystalline trypsin will liberate little or no free amino nitrogen (Van Slyke, Dillon, MacFadyen \& Hamilton, 1941). The present observations indicated that most of the strains had considerable exopeptidase activity, in addition to their proteolytic activity, which resulted in the liberation of free amino acids. This would be in accord with the results of Annison (1956) who found a rapid increase in amino acids and peptides in the rumen after feeding sheep a casein-containing diet. Considerable amidase activity was found in the present strains. The deamidation of casein by mixed rumen micro-organisms and by protozoa has been reported by Warner (1955) and Abou Akkada \& Howard (1962). This amidase activity would explain the ability of propionamide to replace protein in ruminant diets (Hale, 1956).

Few of the isolates had any deaminase activity except in the Bacteroides ruminicola and Selenomonas groups; others such as the Clostridium and Gram-positive cocci are probably of less significance in the total rumen population under normal conditions. B. ruminicola and selenomonads isolated from the bovine rumen have been reported by Bladen, Bryant \& Doetsch (1961) to have deaminase activity. Many of the species reported in the present paper and by Blackburn \& Hobson (1962), which have been isolated for the first time from the sheep rumen, are similar to those reported in the rumen of cattle (Bryant, 1959) and their nitrogen metabolism is similar. In keeping with the observations of Bladen et al. (1961), many of the bacteria studied appeared to utilize ammonia as the main source of nitrogen even in the presence of pre-formed amino acids and although they were hydrolysing casein.

No significant urease activity was demonstrated among the present isolates. The possession of urease has not yet been associated with any of the more common rumen micro-organisms even though urea is rapidly hydrolysed in the rumen.

The authors would like to thank Mr J. McIntosh and Mr R. Summers for skilled technical assistance and Dr P. N. Hobson for his helpful advice and criticism during this work.

\section{REFERENCES}

Abou Akkada, A. R. \& Howard, B. H. (1960). The biochemistry of rumen protozoa. 3. The carbohydrate metabolism of Entodinium. Biochem. J. 76, 445.

Abou Akkada, A. R. \& Howard, B. H. (1962). The biochemistry of rumen protozoa. 5. The nitrogen metabolism of Entodinium. Biochem. J. 82, 313.

Annison, E. F. (1956). Nitrogen metabolism in the sheep. Protein digestion in the rumen. Biochem. J. 64, 705.

Blackburn, T. H. \& Hobson, P. N. (1960a). Proteolysis in the sheep rumen by whole and fractionated rumen contents. J. gen. Microbiol. 22, 272. 
Blackburn, T. H. \& Hobson, P. N. (1960b). Isolation of proteolytic bacteria from the sheep rumen. J. gen. Microbiol. 22, 282.

Biackburn, T. H. \& Hobson, P. N. (1962). Further studies on the isolation of proteolytic bacteria from the sheep rumen. J. gen. Microbiol. 29, 69.

Bladen, H. A., Bryant, M. P. \& Doetsch, R. N. (1961). A study of bacterial species from the rumen which produce ammonia from protein hydrolyzate. Appl. Microbiol. $9,175$.

Bryant, M. P. (1959). Bacterial species of the rumen. Bact. Rev. 23, 125.

Burness, A. T. \& KING, H. K. (1958). Detection of fatty acids on paper chromatograms by means of ninhydrin. Biochem. J. 68, 32P.

Conway, E. J. (1957). Microdiffusion Analysis and Volumetric Error, 4th ed. London: Crosby Lockwood and Son, Ltd.

EAdie, J. M. \& Hobson, P. N. (1962). Effect of the presence or absence of rumen ciliate protozoa on the total rumen bacterial count in lambs. Nature, Lond. 193, 503.

Fulghum, R. S., King, K. W. \& Moore, W. E. C. (1958). Development and comparison of media for the isolation of proteolytic bacteria from the rumen. Bact. Proc. 1958, 22.

Grant, W. M. (1947). Colorimetric micro-method for determination of formic acid. Analyt. Chem. 19, 206.

Hobson, P. N. \& MaNN, S. O. (1961). The isolation of glycerol-fermenting and lipolytic bacteria from the rumen of sheep. J. gen. Microbiol. 25, 227.

Hale, W. H. (1956). Rumen metabolism of non-protein nitrogen. J. Agric. Fd Chem. 4, 948.

Lampson, G. P. \& Singher, H. O. (1960). Colorimetric determination of amino acids in presence of a peptide. Proc. Soc. exp. Biol., N.Y. 103, 368.

LAYNE, E. (1957). Spectrophotometric and turbidimetric methods for measuring proteins. Methods in Enzymology, vol. 3, New York: Academic Press, Inc.

McKenzie, H. A. \& Wallace, H. S. (1954). The Kjeldahl determination of nitrogen. A critical study of digestion conditions-temperature, catalyst and oxidizing agent. Aust. J. Chem. 7, 55.

Stark, J. B., Goodban, A. E. \& Owens, H. S. (1951). Paper chromatography of organic acids. Analyt. Chem. 23, 413.

Van Slyke, D. D., Dillon, R. T., MacFadyen, D. A. \& Hamilton, P. (1941). Gasometric determination of carboxyl groups in free amino acids. J. biol. chem. 141, 627 .

WArner, A. C. I. (1955). Ph.D. Dissertation, Aberdeen University. Some aspects of the nitrogen metabolism of the micro-organisms of the rumen with special reference to proteolysis. 